\begin{tabular}{|l|l|l||}
\hline \multicolumn{2}{|c|}{ PublisherInfo } \\
\hline \hline PublisherName & $:$ & BioMed Central \\
\hline \hline PublisherLocation & $:$ & London \\
\hline \hline PublisherImprintName & $:$ & BioMed Central \\
\hline \hline
\end{tabular}

\title{
Decay in the leprosy genome
}

\begin{tabular}{|l|l|l||}
\hline \multicolumn{2}{|c|}{ ArticleInfo } \\
\hline \hline ArticleID & $:$ & 3989 \\
\hline \hline ArticleDOI & $:$ & $10.1186 /$ gb-spotlight-20010222-03 \\
\hline \hline ArticleCitationID & $:$ & spotlight-20010222-03 \\
\hline \hline ArticleSequenceNumber & $:$ & 60 \\
\hline \hline ArticleCategory & $:$ & Research news \\
\hline \hline ArticleFirstPage & $:$ & 1 \\
\hline \hline ArticleLastPage & $:$ & 2 \\
\hline \hline & & RegistrationDate : 2001-02-22 \\
ArticleHistory & $:$ & OnlineDate $\quad$ 2001-02-22 \\
\hline \hline ArticleCopyright & $:$ & BioMed Central Ltd2001 \\
\hline \hline ArticleGrants & $:$ & \\
\hline \hline ArticleContext & $:$ & 130592211 \\
\hline \hline
\end{tabular}




\section{Jonathan B Weitzman}

Email: jonathanweitzman@hotmail.com

Leprosy, which has been described since biblical times, is caused by the obligate intracellular pathogen Mycobacterium leprae. In the February 22 Nature, Cole et al. report the sequencing of the entire M. lepraegenome (Nature 2001, 409:1007-1011). Pairwise comparison with the genome sequence of the closely related $\mathrm{M}$. tuberculosis revealed that the M. leprae genome has undergone considerable reduction during evolution. The 3.27 megabase $M$. leprae genome contains less than half the number of genes found in the tubercle bacillus (1604 compared to 3959), but has many more pseudogenes (1116 compared to 6). This extensive genome downsizing has been accompanied by the loss of genes important for envelope biogenesis, lipolysis and energy metabolism. Genome decay may explain some unusual characteristics of the leprosy bacillus, such as its exceptionally long doubling time (about 14 days).

\section{References}

1. Nature, [http://www.nature.com]

2. Mycobacterium leprae, [http://www.sanger.ac.uk/Projects/M_leprae]

3. Leproma, [http://genolist.pasteur.fr/Leproma]

4. Deciphering the biology of Mycobacterium tuberculosis from the complete genome sequence. 